\title{
Creative accounting as a global tool for tax optimization
}

\author{
Roman Blazek ${ }^{1, *}$ \\ ${ }^{1}$ University of Zilina, Faculty of Operation and Economics of Transport and Communications, \\ Department of Economics, Univerzitna 1, 01026 Zilina, Slovak Republic
}

\begin{abstract}
.
Research background: Creative accounting is a set of skills that allow people to produce an artistic, scientific or other creative activity that creates new, unusual and acceptable ideas, which are transformed into financial statements, which then form a positive view of the company's economic activities.

Purpose of the article: Creative accounting is a problem all over the world, as it adversely affects the financial statements in each country. The article describes models that help reveal the creativity of accountants and financiers. Procedures for identifying possible accounting delays are based on analytical models. In particular, it is complex statistical methods or data collection techniques that identify hidden, unusual patterns that indicate fraud. These analytical models are therefore used to detect various errors and fraud in accounting.

Methods: Analytical models will be available to identify different methods of accounting abuse. Interest is placed on the analytical models of Beneish model and the Modified Jones model. The main objective of using these models is to reveal creative accounting in sector A - Agriculture, forestry and fishing. Fraud is investigated using sophisticated analytical methods that reveal improved data.

Findings \& Value added: Creative accounting in the conditions of the Slovak Republic but also globally is still not possible completely to reveal. The value added of this article can be mentioned as the benefit for potential business partners as well as investors interested in the analysed sector and the other hand for the other for the state administration.
\end{abstract}

Keywords: creative accounting; purposeful manipulation; tax optimization; falsification; signs of economic crime

JEL Classification: $F 65 ; M 41 ; G 32$

\footnotetext{
* Corresponding author: roman.blazek@stud.uniza.sk
} 


\section{Introduction}

Economic crime in the world, but also in Slovakia, has taken on enormous proportions over the years. People did not pay much attention to the correctness of accounting, as for many years the balanced stocks of assets and liabilities at the end of the accounting period were enough for them. So the accountants did their job as best they could and the companies gave a correct and true picture of their accounting. Over the years, when business owners began to use different types of financing for their activities, whether from their own resources or from others, accountants had to cope with the influx of new and new funds into the company, which did not always correspond to the situation the company spent on its business. As not all of the money came from the owners, business owners were forced to turn to the accountants again and suggest that they monitor indicators that could indicate various favourable as well as unfavourable business directions. These indicators were able to reveal various ailments that arose from the company's management and show the owners where their weaknesses are and where, on the contrary, they significantly outperform others, as without benchmarking there would be no competition in the world and therefore consumers would not receive high quality products, low prices at optimal costs. Wokukwu argues that in fact, transparency in the financial reporting system is of utmost importance because individuals, potential investors, creditors and regulators have to make investment decisions based on corporate financial reports [1].

The aim of the article is to point out the seriousness of the negative effect of creative accounting on the company's accounting, which in parallel negatively benefits the state, as companies pay the required amount of tax and thus harm not only the state, as they do not meet the state budget but also the business environment for business entities.

The article is divided into sections such as literature review, which contains a crosssection of definitions from various authors who are involved in the discovery of creative accounting. The next chapter, Materials and Methods, captures two models that are worldrenowned and used to detect accounting manipulation. These are the Beneish models and the Modified Jones model. The following chapter captures the results obtained by applying the above models, which were applied to companies in the sector A - Agriculture, Forestry and Fisheries, which were further selected on the basis of criteria determined on the basis of the subjective opinion of the author.

\section{Literature review}

Ian Griffiths writing from the perspective of a business journalist, observes: Every company in the country is fiddling its profits. Every set of published accounts is based on books which have been gently cooked or completely roasted. The figures which are fed twice a year to the investing public have all been changed in order to protect the guilty. It is the biggest con trick since the Trojan horse ... In fact this deception is all in perfectly good taste. It is totally legitimate. It is creative accounting [2]. Schipper observes that 'creative accounting' can be equated with 'disclosure management', 'in the sense of a purposeful intervention in the financial reporting process' [3]. Merchant and Rockness examines management manipulation of accounting information within two firms (i.e. information used in internal reporting by divisions) drawing upon both interview and questionnaire data. The research found that 'managers acknowledged manipulative behaviours and short-term orientations' [4]. According to Gowthorpe and Amat, the compilers are able to manipulate the view of economic reality presented in statements that are interesting to the other party [5]. MilesiFerretti states in his study that fiscal rules create space for creative accounting. [6] This statement is further extended by von Hagen and Wolff, who state that companies are circumventing government regulations and are trying in some way to return to creative 
accounting [7]. The authors Bernoth and Wolff noted that companies are creating interest rates among bond yields in the European Union [8]. We can also see cases of the use of creative accounting in the field of energy, specifically in the field of electricity generation, which produces about $25 \%$ of global greenhouse gases. Businesses that consume electricity are then kept in documents, which can be used to find out how much electricity they have consumed. The authors Brander, Gillenwater and Ascui found that even in this case, companies are able to provide irrelevant information on greenhouse gas management [9]. The authors Vinnari and Näsi argue that it is necessary for accounting to be taken on the basis of accruals as well, as this distinction offers opportunities for the use of creative accounting, which necessitates control in this area as well [10]. Naser questioned senior corporate auditors about their experience of creative accounting. They were able to conclude that a significant proportion of all categories of companies employ creative accounting techniques to some extent [11].

Krupová argues that creative accounting can be considered to be "a process of manipulating accounting data in order to transform financial statements from what they should be to what their creators would like and the processes in which direct economic transactions are carried out so that it was possible to achieve favourable results in the accounts" [12].

According to Mulford and Comiskey: „The potential for creative accounting is found in six principal areas: regulatory flexibility, a dearth of regulation, a scope for managerial judgement in respect of assumptions about the future, the timing of some transactions, the use of artificial transactions and finally the reclassification and presentation of financial numbers. Even in a highly regulated accounting environment such as the USA, a great deal of flexibility is available" [13]. Hamada complements this statement, stating that "creative accounting has played an important and effective role in the preparation of financial statements, which has had an impact on the maintenance of stock prices, the recognition of income or the smoothing of income. All risk was subsequently lost between the numbers in the financial statements" [14]. Jones explains to the readers of his publication that "any company which does not meet the basic characteristics of true accounting uses creative accounting" [15]. Khanh and Thu who examined Vietnamese listed companies that committed management earnings, shared this view [16]. Hoang \& Joseph in his study that the convergence of Vietnamese accounting to international accounting standards minimized the use of creative accounting in listed companies [17].

Khattab uses the following definition: "Creative accounting is the process of changing accounting numbers from the real form to the desired form to achieve benefits for the company and its management via the Internet, disclosing this information by choosing between accounting principles alternatives or ignoring some of them" [18]. According to the results of the authors Susanto, Pirzada \& Adrianne it was proved that e.g. tax aggression, institutional ownership and leverage also affect earnings management [19].

Oxford Interpretive Dictionary offers a similar definition, which reads: "By using gaps in accounting regulation, we try to gain an advantage, or more favourable results of the submitted financial data."[20] Bhasin emphasized that "innovative aspects of creative accounting are implemented through manoeuvring with numbers, which implies that innovation is an essential part of creative accounting practices in accounting practices." good or bad? "The final answer to this question can be found in the "purpose" for which it is used and the "way" in which it is applied. After examination and analysis, it was concluded that "creative accounting is like a double-edged cold weapon that can be used or misused by management. In the case of abuse, the only mistake is management and not the creative accounting system itself" [21].

Fizza and Qaisar add that these creative accounting practices in financial reporting have been described as "the mastery of calculation falsification, the creative art of balance sheet 
presentation, and brilliant saving of money" [22]. Okoro and Okoye argue that creative accounting helps organizations mitigate year-on-year changes in profits by shifting profits from prosperous years to less successful years, so that profit fluctuations are more stable, respectively. that the reporting of profits is on average at the same level, without significant deviations [23].

Kliestik, Valaskova, Nica, Kovacova, \& Lazaroiu can only confirm this claim, as their publication shows that companies use earnings management in order to compensate for fluctuations in their profits in order to report profits in each reference period [24]. The authors Siekelova, Androniceanu, Durana \& Michalikova also state in their publications that the use of earnings management in a company depends on the size of the company, as the result of their study was the fact that there is a statistical difference in earnings management using one-way ANOVA [25].

Al-Natsheh and Al-Okhed define creative accounting as "some or all of the steps taken to play a game of financial information, which include the arbitrary choice of applying accounting principles and fraud in financial management and any other steps taken to make a profit, manage and balance income" [26].

According to Falcón, Sanchez and Vizcaino, "creative accounting is in the environment of a manager and an accountant who manipulate business information so subtly that the results they report are so confidential that they do not reflect, at first glance, any sign of manipulation. Accounting is therefore, in essence, the work of senior workers, who are full of high creativity and make full use of this feature" [27].

According to Liberto, creative accounting is defined relatively differently, namely that "accounting processes are used that comply with the conditions set by laws and regulations, but differ from what they want to achieve. Creative accounting thus benefits from cracks in accounting standards to improve the organization's image" [28]

Svabova, Valaskova, Durana and Kliestik state in their publications that in the V4 countries there are indicators that indicate the use of creative accounting in these countries [29].

Based on this and other publications, I decided to address this issue in this article and look in more detail at the sector A - Agriculture, forestry and fishing in the Slovak Republic.

\section{Materials and Methods}

Creative accounting is a tool that combines creativity, adaptability and gaps in laws, accounting standards and restrictions. This tool can be largely on the margins of the law, even though the techniques used in creative accounting are often illegal. Among the techniques that have been identified are e.g. non-compliance with the precautionary principle, distortion of the property at the time of its acquisition, replacement of the technical improvement of the property for repair and vice versa. These techniques are part of one name, namely window dressing. In addition to window dressing, there is also off-balance sheet financing, which consists of exchanging financial leasing for operating, non-recognition of liabilities arising from unpaid receivables, loans reported as sales, provisioning, incorrect choice of depreciation method, use of company assets for private purposes, loan receivable or fictitious invoices. To reveal the use of these techniques, models have been developed that are known and globally recognized. The most important models are the Modified Jones model and the Beneish model. Of course, there are other models, such as. Red Flags, Benford's law, Piotroski score, Jones model, etc. Models that achieve very good results include the Beneish model and the Modified Jones model.

The Beneish model is a very well thought-out model that consists of five or eight parameters, where each parameter has its own indicator of manipulation and thus it is much easier to reveal the data that has been manipulated. The formula itself has a manipulation 
indicator, so working with this model makes it easier for people to examine whether or not the company has manipulated accounting data, entries, pre-accounting, account movements.

The main definitional relationship is based on the equation:

$$
\begin{gathered}
M=-4,84+0,92 \cdot D S R I+0,528 \cdot G M I+0,404 \cdot A Q I+0,892 \cdot S G I+ \\
0,115 \cdot D E P I+0,172 \cdot S G A I+4,679 \cdot T A T A+0,327 \cdot L V G I
\end{gathered}
$$

Where

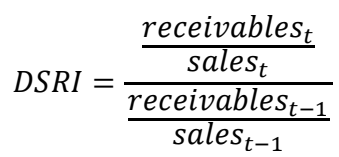

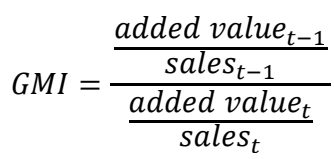

$$
\begin{aligned}
& A Q I=\frac{1-\frac{\text { current asset }_{t}-P P E_{t}-\text { equities }_{t}}{\text { total assets }_{t}}}{1-\frac{\text { current assets }_{t-1}-P P E_{t-1}-\text { equities }_{t-1}}{\text { total assets }_{t-1}}} \\
& S G I=\frac{\text { sale }_{t}}{\text { sales }_{t-1}} \\
& D E P I=\frac{\frac{\text { depreciation }_{t-1}}{P P E_{t-1}+\text { depreciation }_{t-1}}}{\frac{\text { depreciation }_{t}}{P P E_{t}+\text { depreciation }_{t}}} \\
& G A I=\frac{\frac{{\text { fixed } \text { costs }_{t}}_{\text {sales }}}{{\text { fixed } \text { cost }_{t-1}}_{\text {sales }} \text { t-1 }}}{\text { sater }} \\
& L V G I=\frac{\frac{\text { current liabilities }_{t}+\text { long }- \text { term }_{\text {commitments }}}{\text { total asset }_{t}}}{\frac{\text { current liabilities }_{t-1}+\text { long }_{\text {term }} \text { commitments }_{t-1}}{\text { total asset }_{t-1}}} \\
& \operatorname{TATA}=\frac{\frac{\text { operating profit }_{t}-C F_{t}}{\text { total assets }_{t}}}{\frac{\text { operating profit }_{t-1}-C F_{t-1}}{\text { total assets }_{t-1}}}
\end{aligned}
$$

The modified Jones model is recognized and achieves very accurate results in detecting companies using creative accounting to improve their economic level. This model is one of the best models in the detection of manipulation in the Slovak Republic, as evidenced by the result of research by employees of the Department of Economics from the University of Zilina.

$$
\frac{N D A_{i t}}{A_{i t-1}}=\frac{T A_{i t}}{A_{i t-1}}=\alpha_{0} \frac{1}{A_{i t-1}}+\alpha_{1} \frac{\Delta R E V_{i t}-\Delta R E C_{i t}}{A_{i t-1}}+\alpha_{2} \frac{P P E_{i t}}{A_{i t-1}}+\varepsilon_{i t}
$$




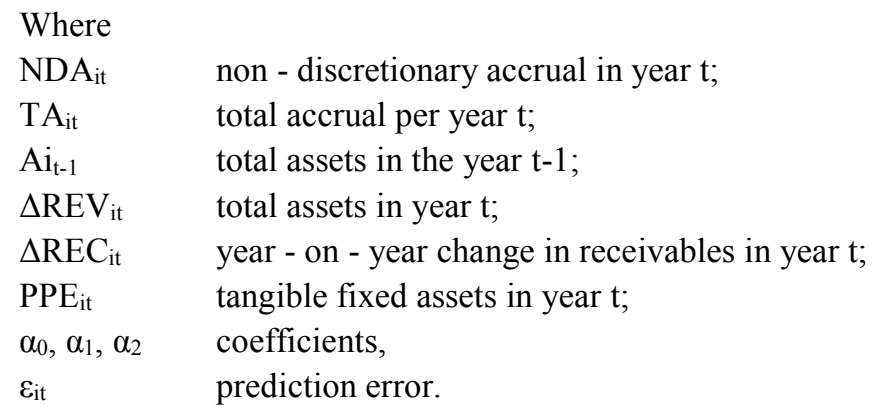

Both models can detect the use of creative accounting. Their use is very beneficial for auditors and financial administration staff who try to detect illegal behaviour of the company, as this behaviour has a negative effect on the tax base, some of which companies have to send to the state budget, which is the most important financial tool to enforce the state. economic policy. Upon successful detection of companies that commit manipulations of financial statements, a legal proceeding is initiated, in which the company is forced to pay a large amount of the fine. Unfortunately, there are also cases where the models are not $100 \%$ accurate, which in the final analysis come out as companies that do not manipulate and thus can, by not complying with the law, enrich or avoid paying tax to the state budget, which has a negative impact on the state, but also to the business environment in the country or in the world.

These two models, which are globally recognized, were also applied to the conditions of the Slovak Republic, specifically to sector A - Agriculture, forestry and fishing.

The data used to create the Beneish model and the Modified Jones model were obtained from the European AMADEUS database, which contains financial information on more than 21 million European companies, of which almost 10 million. from Central and Eastern Europe. The AMADEUS database captures 292,013 enterprises in Slovakia, of which 8,659 enterprises belong to the agriculture, forestry and fishing sector. The years analysed for sector A - Agriculture, forestry and fishing are: 2018, 2017, 2016 and 2015. It follows that the number of enterprises will decrease and thus, after selecting the above years, 3,720 enterprises remain. Subsequently, the criteria that the company had to meet throughout the period considered were set and by which the companies were selected. The required criteria are as follows:

- minimum value of total assets $=€ 3,000,000$,

- $\quad$ minimum value of sales $=€ 2,000,000$,

- $\quad$ minimum net profit $=€ 100,000$.

The set criteria was met by 46 companies located in the monitored sector.

\section{Result and Discussion}

The Beneish model, like the Modified Jones model, was applied over a three-year horizon. After applying the Beneish model, the following facts were found: 
Table 1. M-score table for monitored companies from industry A.

\begin{tabular}{|l|c|c|c|}
\hline & $\mathbf{2 0 1 8}$ & $\mathbf{2 0 1 7}$ & $\mathbf{2 0 1 6}$ \\
\hline Above the limit & 40 & 44 & 43 \\
\hline Below the limit & 6 & 2 & 3 \\
\hline
\end{tabular}

In individual years, the development of handling and non-handling companies has changed minimally. In 2016, 3 companies were identified that did not manipulate the financial statements, which represents $6.5 \%$ of the total number of analysed companies. The remaining 43 companies, which represents $93.5 \%$, manipulated their financial statements. In the following year 2017, only 2 enterprises were included in the group of non-manipulative enterprises, which represented $4 \%$ of enterprises, out of the total number of 46 analysed enterprises in the given year. The remaining $96 \%$, so 44 companies, manipulated the financial statements. In 2018, the number of non-manipulative enterprises increased by $300 \%$, as 6 enterprises that did not manipulate the financial statements were identified, which represented $13 \%$ of the monitored enterprises in the given year. The remaining 40 companies, so $87 \%$, manipulated their financial statements. From the results obtained using the Beneish model, it can be seen that a large proportion of companies, almost $85 \%$ of the industry, tend to manipulate their financial statements.

The Modified Jones model was chosen as the second model used to detect creative accounting. This model is one of the best, as evidenced by the evidence from the study by Valaskova et al [30], where it was found that this model is the most suitable for detecting companies in the Slovak Republic. In the case of the modified Jones model, it is advantageous to determine the deviation that divides the companies in terms of handling. It is a very good tool, e.g. for auditors who, on the basis of the chosen derogation, are able to identify more precisely those undertakings which have committed manipulation and sought to enrich themselves to their advantage. The auditors then examine all the data that enters the modified Jones model, as some of this data, but some or all of the data may be manipulated, means that the company has acted unlawfully and in breach of accounting principles that clearly state that accounting should have a true and fair view.

For this article, the deviation was set at \pm 0.005 (based on expert judgment) from zero, and this range is considered to be not too different from zero, which indicates non-profitmaking enterprises. Based on this discrepancy, it is possible to determine how many companies have manipulated and how many companies have not manipulated their financial statements. In 2016, 5 companies did not manipulate their financial statements, which represents $11 \%$. The remaining 41 companies, so $89 \%$, manipulated their financial statements. In the following year 2017, there was a decrease in enterprises that did not manipulate their financial statements by $40 \%$, i.e. non-manipulative enterprises were 2 , which represented $4 \%$ of the total number of analysed enterprises. However, there was an increase in handling companies, where a positive growth trend was recorded, namely an increase of $7 \%$, so 44 companies manipulated financial statements, which in a given year represented $96 \%$ of the total number of monitored companies. In 2018, the number of companies that did not manipulate the financial statements increased, namely by $150 \%$, i.e. to 3 companies. There was a smaller drop in the development of handling companies, namely by $3 \%$, which represents 1 company. Thus, in a given year, $7 \%$ of companies did not manipulate their financial statements and the remaining $93 \%$ of companies committed manipulation.

Table 1. Table DA for the monitored enterprises in sector A.

\begin{tabular}{|l|c|c|c|}
\hline & $\mathbf{2 0 1 8}$ & $\mathbf{2 0 1 7}$ & $\mathbf{2 0 1 6}$ \\
\hline Above the limit & 43 & 44 & 41 \\
\hline Below the limit & 3 & 2 & 5 \\
\hline
\end{tabular}


From the above facts, it can be seen that even the modified Jones model reveals a large number of companies that have manipulated their financial statements. In doing so, they tried to attract the attention of investors, or they tried to cover up their mismanagement over the years and adjust their statements to such an extent that there was no suspicion that the company would not be able, e.g. pay their debts.

\section{Conclusions}

The models revealed that a number of the companies surveyed resort to manipulating their accounts, which does not shed a good light on companies and entrepreneurs operating in sector A. Despite the calculations, it should be noted that these models are quite theoretical, which may have as a result, their credibility is not $100 \%$. It should also be noted that the data obtained, which were applied in this work are from the AMADEUS database, which captures the complete financial statements of companies. These data should be reliable and accurate, but the most ideal data would only be obtained by directly visiting the companies concerned and addressing the staff working with the company's analyses. Unfortunately, this "advantage" could not be exploited, as it would require contacting 46 employees (at least one for each company) who would be willing to pay attention and make sensitive financial and accounting data available. Nevertheless, the application of data from the AMADEUS database was able to confirm the information circulating in recent years about various unfair practices in the sector under review, from various agro-subsidies to Euro funds, which did not always end up being applied for the purposes for which they were provided.

Creative accounting can certainly be fought. Tighter sanctions for using this evergreen or adopting stricter standards could help. This form of manipulation of financial statements is still poorly specified in the world. Therefore, creative accounting is on the rise in the Slovak Republic. The measures that are being put in place to combat this phenomenon are being taken late. Therefore, it would be much more sensible to introduce measures to eliminate this unfair reporting more often and not until creative accounting reaches enormous proportions and the only possible solution is then huge fines and the use of court services.

This research was financially supported by the Slovak Research and Development Agency — Grant NO. APVV-17-0546: Variant Comprehensive Model of Earnings Management in Conditions of the Slovak Republic as an Essential Instrument of Market Uncertainty Reduction.

\section{References}

1. Wokukwu, K. (2015). Creative Accounting: Unethical Accounting And Financial Practices Designed To Boot Earnings And To Meet Financial Market Expectations Stillman College. Journal Of Business \& Economic Policy, 2(1), 39-48.

2. Griffiths, I. (1986). Creative Accounting: How to make your profits what you want them to be. Unwin paperbacks.

3. Schipper, K. (1989): Commentary on earnings management. Accounting Horizons, 3(4), 91-102.

4. Merchant, K. A., Rockness, J. (1994). The ethics of managing earnings: An empirical investigation. Journal of Accounting and Public policy, 13(1), 79-94.

5. Gowthorpe, C., Amat, O. (2005). Creative accounting: some ethical issues of macro-and micro-manipulation. Journal of Business Ethics, 57(1), 55-64.

6. Milesi-Ferretti, G. M. (2004). Good, bad or ugly? On the effects of fiscal rules with creative accounting. Journal of Public Economics, 88(1-2), 377-394. 
7. Von Hagen, J., Wolff, G. B. (2006). What do deficits tell us about debt? Empirical evidence on creative accounting with fiscal rules in the EU. Journal of Banking \& Finance, 30(12), 3259-3279.

8. Bernoth, K., Wolff, G. B. (2008). Fool the markets? Creative accounting, fiscal transparency and sovereign risk premia. Scottish Journal of Political Economy, 55(4), 465-487.

9. Brander, M., Gillenwater, M., Ascui, F. (2018). Creative accounting: A critical perspective on the market-based method for reporting purchased electricity (scope 2) emissions. Energy Policy, 112, 29-33.

10. Vinnari, E. M., Näsi, S. (2008). Creative accrual accounting in the public sector:'Milking'water utilities to balance municipal budgets and accounts. Financial Accountability \& Management, 24(2), 97-116.

11. Naser, K. H. (1993). Creative financial accounting: its nature and use. Prentice Hall.

12. Krupová, L. (2001). Creative accounting: The abuse of accounting-possibilities and limits. Praha: Chamber of Auditors of the Czech Republic.

13. Mulford, C. W., Comiskey, E. E. (2005). The financial numbers game: detecting creative accounting practices. John Wiley \& Sons.

14. Hamada, R. (2010). Role of Audit Committees in Limiting Creative Accounting Practices (Field Study). Damascus University Journal of Economic and Legal Sciences, 26(2).

15. Jones, M. J. (2010). Creative accounting, fraud and international accounting scandals. John Wiley \& Sons.

16. Hoang, K. M. T., Phung, T. A. (2019). The effect of financial leverage on real and accrual-based earnings management in Vietnamese firms. Economics \& Sociology, 12(4), 299-333.

17. Hoang, T. C., \& Joseph, D. M. (2019). The effect of new corporate accounting regime on earnings management: Evidence from Vietnam. Journal of International Studies, 12(1), 93-104.

18. Khattab, M. S. Y. A. (2012). A proposed framework for activating corporate governance in the extraction of some methods of creative accounting. Journal of Public Administration, 2, 218-219.

19. Susanto, Y. K., Pirzada, K., Adrianne, S. (2019). Is tax aggressiveness an indicator of earnings management?. Polish Journal of Management Studies, 20(2), 516-527.

20. Oxford university press (2019). Lexico. Retrieved from http://www.oxforddictionaries.com/definition/english/creativeaccountancy? $q=$ creative + accounting

21. Bhasin, M. L. (2015). Creative accounting practices in the Indian corporate sector: An empirical study. International Journal of Management Sciences and Business Research, 4(10), 35-52.

22. Fizza, T., Qaisar, A. M. (2015). Creative accounting and financial reporting: Model development and empirical testing. International Journal of Economics and Financial Issues, 5(2), 544-551.

23. Okoro, E. G., Okoye, E. I. (2016). Taming creative accounting via international financial reporting standards: The Nigerian scenario. Business Trends, 6(4), 11-17.

24. Kliestik, T., Valaskova, K., Nica, E., Kovacova, M., Lazaroiu, G. (2020). Advanced methods of earnings management: monotonic trends and change-points under spotlight in the Visegrad countries. Oeconomia Copernicana, 11(2), 371-400. 
25. Siekelova, A., Androniceanu. A., Durana P., Frajtova Michalikova. K. (2020). Earnings management (EM), initiatives and company size: An empirical study. Acta Polytechnica Hungarica, 17(9), 41-56.

26. Al-Natsheh, N., Al-Okdeh, S. (2020). The impact of creative accounting methods on earnings per share. Management Science Letters, 10(4), 831-840.

27. Falcón, V. V., Sánchez, F. D. J. C., Vizcaino, M. E. G. (2019). An axiological look at Creative Accounting. Dilemas Contemporáneos: Educación, Política y Valore, 6, 44.

28. Liberto, D. (2019, May 2). Creative Accounting. Retrieved from : https://www.investopedia.com/terms/c/creative-accounting.asp

29. Svabova, L., Valaskova, K., Durana, P., Kliestik, T. (2020). Dependency Analysis Between Various Profit Measures and Corporate Total Assets for Visegrad Group's Business Entities. Organizacija, 53(1), 80-90.

30. Valaskova, K., Svabova, L., \& Durica, M. (2017). Verification of prediction models in conditions of the Slovak agricultural resort. Economics, Management, Innovation, 9(3), 30-38. 